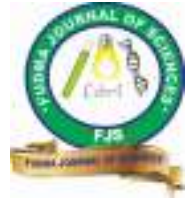

\title{
DETERMINATION OF THE PROXIMATE AND MINERAL CONTENTS OF DESERT DATE KERNEL (BALANITES AEGYPTIACA LINN.) AND THE PHYSICAL AND CHEMICAL CHARACTERISTICS OF THE KERNEL OIL AVAILABLE IN KANO STATE, NIGERIA
}

\author{
${ }^{* 1}$ Datti, Y., ${ }^{1}$ Yahya, A. T., ${ }^{1}$ Koki, I. B., ${ }^{1}$ Lado, U. A., ${ }^{1}$ Musbahu, L., ${ }^{1}$ Shuaibu, M. M., ${ }^{2}$ Ahmad, U. U., ${ }^{2}$ Adamu, G. A., \\ ${ }^{2}$ Umar, A. and ${ }^{1}$ Nura T.
}

\author{
${ }^{1}$ Department of Chemistry, Yusuf Maitama Sule University, Kano. \\ ${ }^{2}$ Department of Science Laboratory Technology, School of Technology Kano. \\ ${ }^{3}$ Department of Chemistry, School of Science Education, FCE (T) Bichi.
}

Corresponding author's email: yaudatti@gmail.com

\begin{abstract}
The desert date (Balanites aegyptiaca) is one the most important relish trees found in many African countries. In this study the proximate and mineral compositions of the desert date kernel, as well as some of the physical and chemical properties of its oil were analyzed using standard procedures. The results of the proximate composition revealed the following mean concentrations: Moisture content 3.19\%; ash content 2.89\%; fat content $39.63 \%$; crude protein content $33.75 \%$; crude fiber content $13.06 \%$ and carbohydrate content $7.48 \%$. And the mineral content revealed the following mean concentrations: Potassium $1.120(\mathrm{mg} / 100 \mathrm{~g})$; calcium $0.390(\mathrm{mg} / 100 \mathrm{~g})$; sodium $0.801(\mathrm{mg} / 100 \mathrm{~g})$; magnesium $0.142(\mathrm{mg} / 100 \mathrm{~g})$; iron $0.0024(\mathrm{mg} / 100 \mathrm{~g})$; manganese $0.01512(\mathrm{mg} / 100 \mathrm{~g})$; zinc $0.0082(\mathrm{mg} / 100 \mathrm{~g})$; copper $0.00225(\mathrm{mg} / 100 \mathrm{~g})$; nickel $0.00582(\mathrm{mg} / 100 \mathrm{~g})$; cobalt $0.002623(\mathrm{mg} / 100 \mathrm{~g})$ and chromium $0.003224(\mathrm{mg} / 100 \mathrm{~g})$. While the results for the physical analysis of the kernel oil revealed the following: Color pale yellow; density $\mathrm{g} / \mathrm{cm}^{3} 0.910$; specific gravity 0.907 ; refractive index 1.458 and viscosity 19.68. And on the other hand, the results for the chemical analysis of the kernel oil revealed the following: acid value $3.06 \mathrm{mgKOH} / \mathrm{g}$; free fatty acid 1.27 ; peroxide value $3.71 \mathrm{mEq} / \mathrm{Kg}$; saponification value $198 \mathrm{mg} / \mathrm{KOH} / \mathrm{g}$ and iodine value $98.73 \mathrm{100} / \mathrm{g}$. All the results were compared and found to be within the FAO/WHO standards. The seeds kernel of this plant was found to be high nutritional value, while its oil can be a good source of raw material for many oil-based products.
\end{abstract}

Keywords: Proximate composition, Mineral contents, Balanite aegyptiaca, Kernel, Kernel oil.

\section{INTRODUCTION}

African countries are blessed with different species of plants with medicinal, nutritional and socio-economic importance. Among these plants is the Balanite aegyptiaca Linn., a tree that is more valued for its fruits and kernels. Popularly known as desert date, Balanite aegyptiaca is an all-important multipurpose tree plant found in almost all African countries (Clement et al., 2011). The desert date fruit and its kernel are widely used in many ways in Nigeria and other African countries especially during the dry season and drought periods (Lockett et al., 2000). The kernel of this plant is traditionally also used as remedy to certain ailments including intestinal worm infection, syphilis, jaundice, malaria, dysentery, constipation, haemorroid and epilepsy among others (Daya and Vaghasiya, 2011). The stem of the desert date is used for shade, mulch, windbreak, gum (Guinand et al., 2001), poles, timber, firewood, charcoal, tool handle, utensils, food and fodder (Elseed et al., 2002). It has also been used as an oral antidiabetic drug especially in the Egyptian folk medicine (Kamel 1991; Gnoula et al., 2008; Nasser et al., 2016), and for ages it has been used in the treatment of several disorders and diseases (Charity et al., 2018).

This all-important tree is used for food and fodder in almost all African countries and the South Asia (Billore 1988; Elseed et al., 2002). The protein content of the fruit of this plant is believed to be superior than that in guava, mango, banana and papaya, with the fleshy fruit containing high carbohydrates, some essential minerals, steroidal saponins, vitamins $\mathrm{A}$ and $\mathrm{C}$ for human (Al-Thobaiti and Abu-Zeid 2018). The kernel produces high quality edible oil (Obidah et al., 2009) with large number of medicinal properties (Hanan et al., 2009). This oil is regarded as vegetable oil because it is obtained from a plant source, with the main importance of vegetable oils being the food values they possess (Adebayo et al., 2012). The edible seed kernel of this important plant is rich in oil, protein, minerals among others (Vonmaydell 1986; Elfeel and Warrag 2011). Oils are heterogeneous biochemical substances with the property of being insoluble in water, but soluble in organic polar solvents like chloroform, benzene, diethyl ether, etc. (Author 1995). In quality aspect, it is similar to sesame and groundnuts oils (Abu Al-Futuh, 1983; Obidah et al., 2009), with the oil used as a biodiesel (Chapagain et al., 2009; Gutti et al., 2012; Kumawat et al., 2012).

The objective of this study is to determine the proximate and mineral composition of desert date kernel Balanites aegyptiaca, and also to investigate the physical and chemical characteristics of the desert date kernel oil.

\section{MATERIALS AND METHODS}

\section{Sample Collection and Preparation}

The fruits of Balanites aegyptiaca (desert date) were purchased from Rimi market in Kano State, Nigeria and brought to the department of Biological Sciences, Yusuf Maitama Sule University, Kano, for identification by a plant taxonomist. The 
plant was identified and authenticated and issued a voucher specimen number YUHAN 0058. The fruits were crushed using a steel hammer to obtain the kernels, which were then air-dried and then ground using mortar and pestle (Bayero et al., 2019). The ground kernel was then packed in an air tight container and then stored in a desiccator (containing silica gel) ready for further analysis.

All the chemicals and reagents used were of analytical grade.

\section{Extraction of the Sample}

The powdered sample $(50 \mathrm{~g})$ was soaked in $300 \mathrm{ml}$ of absolute ethanol for $72 \mathrm{hrs}$, and stored away from direct light. The supernatant was decanted and filtered using filter paper and the filtrate was evaporated to dryness, and then stored in sample bottles at room temperature to avoid any biological degradation (Bayero et al., 2019).

\section{Determination of the Proximate Composition of the Kernel} Moisture Content

The moisture content was determined according to of the Association of Official Analytical Chemists (AOAC, 2008). Here $2 \mathrm{~g}$ of the dried powdered sample was transferred into a pre-weighed dish. The sample was then placed into an oven at $105^{\circ} \mathrm{C}$ until a constant weight was obtained. After drying, the sample was removed and transferred to a desiccator and cooled to room temperature before reweighing. Triplicate results were obtained for each sample and the mean value was reported to three decimal points according to the following formula:

$$
\text { Moisture Contents (\%) }=\frac{W 1-W 2}{W 1} X 100 \%
$$

where;

W1= Sample weight before drying

W2 =Sample weight after drying.

\section{Ash Content}

The ash content of the desert date was determined according to the method described by Pearson (1981) and adopted by Ifeoma et al., (2010). Here $5 \mathrm{~g}$ of the dried powdered sample was transferred into a pre-weighed and tarred porcelain crucible and placed into a muffle furnace (Yamato, DX-302C) at $550^{\circ} \mathrm{C}$ until a white-gray ash was obtained. The crucible was the transferred to a desiccator were it was allowed to cool to room temperature and the reweighed. The ash content was then calculated as a percentage based on the initial weight of the sample using the following formula:

$$
\text { Ash Contents }(\%)=\frac{(\text { Weight of Crucible }+ \text { Ash })-(\text { Weight of Crucible })}{\text { Initial Weight of the Sample }} \times 100 \%
$$

\section{Fat Content}

The fat content of the sample was determined according to the official method of AOAC (2008). Here $5 \mathrm{~g}$ of the dried powdered sample was transferred into an extraction thimble. The extraction thimble was then positioned into the Soxhlet attachment, with the pre-weighed round-bottomed flask containing $90 \mathrm{ml}$ of petroleum ether. The flask was then fitted under the Soxhlet attachment and the whole set-up was placed on a heating mantle for 6 hours at $100^{\circ} \mathrm{C}$. At the end of the extraction period, the flask was disconnected from the unit and the solvent was redistilled. Later, the flask with the remaining crude petroleum ether extract was cooled to room temperature in a desiccator and then reweighed. The fat content was then calculated using the following formula:

$$
\text { Fat Content }(\%)=\frac{(\text { Weight of Flask }+ \text { the Extract })-(\text { Weight of Empty Flask })}{\text { Initial Weight of the Sample }} \times 100 \%
$$

\section{Crude Protein Content}

The crude protein content of the dried powdered kernel of the desert date was determined by the micro-Kjeldahl method using a copper sulphate-sodium sulphate catalyst in accordance with the official method of the AOAC (2008). Here $2 \mathrm{~g}$ of the sample, $4 \mathrm{~g}$ of the Kjeldahl catalyst $\left(\mathrm{Na}_{2} \mathrm{SO}_{4}\right)$ and $25 \mathrm{ml}$ were transferred into a Kjeldahl digestion flask. The flask was then placed into a Kjeldahl digestion unit for about 2 hours until a colorless digest was obtained, and then the flask was left to cool down to room temperature. Distillation of ammonia was carried out into $25 \mathrm{~m} 1$ of $2 \%$ boric acid using $20 \mathrm{~m} 1$ distilled water and $70 \mathrm{~m} 1$ of $45 \%$ sodium hydroxide solution. Finally, the distillate was titrated with standard solution of $0.1 \mathrm{~N} \mathrm{HCl} \mathrm{using} 3$ drops of bromocresol green as indicator, until a brown reddish color was observed. Using the same procedure, a blank test was analyzed using water instead of the test sample. The percentage nitrogen content of the sample was calculated as follows, as adopted by Gemechu et al., (2015):

$$
\% \text { Nitrogen by Weight }=\frac{(V s-V b) H C l \text { consumed } x N \mathrm{HCl} x 1.4007}{\text { Sample Weight }} \times 100
$$

Percentage Crude Protein $=\%$ N x 6.38

where:

$\mathrm{Vs}=$ Volume of $\mathrm{HCl}$ used for titration of the sample

$\mathrm{Vb}=$ Volume of $\mathrm{HCl}$ used for titration of the blank.

Crude Fiber Content

The percentage crude fiber of the desert date kernel was determined according to the official method of the AOAC (2008). Here 2 $\mathrm{g}$ of the dried powdered sample was placed into a conical flask containing $20 \mathrm{~m} 1$ of $2 \% \mathrm{H}_{2} \mathrm{SO}_{4}$, and the flask was then fitted to a condenser and allowed to boil for 30 minutes. After this digestion, the flask was removed and the digest filtered under vacuum 
through a proclain filter crucible, with the precipitate repeatedly rinsed with distilled boiled water followed by boiling in $20 \mathrm{ml} 2 \%$ $\mathrm{NaOH}$ solution for 30 minutes under reflux condenser and the precipitate was filtered, rinsed with hot distilled water, followed by $20 \mathrm{~m} 10 \mathrm{0f} 96 \%$ ethyl alcohol and $20 \mathrm{ml}$ diethyl ether. The crucible was finally dried overnight to a constant weight at a temperature of $105^{\circ} \mathrm{C}$, then cooled in a desiccator, reweighed, and then ashed in a muffle furnace at a temperature of $550^{\circ} \mathrm{C}$ until a constant weight was obtained, and the difference in weight was considered as the crude fiber content. The percentage fiber content was calculated using the formula as reported by Francesca et al., (2015).

$$
\text { Fiber Content }(\%)=\frac{(\text { Wt. of Cruc. }+ \text { Dry Residue })-(\text { Wt of Cruc. }+ \text { Ignited Residue })}{\text { Weight of the Sample }} \times 100 \%
$$

\section{Total Carbohydrates}

The total carbohydrates content of the dried powdered sample of the desert date was calculated by difference according to the following equations (as reported by Francesca et al., (2015).

$$
\% \text { Carbohydrate }=100-(\% \text { Moisture }+\% \text { Fat }+\% \text { Ash }+\% \text { Fiber }+\% \text { Protein })
$$

\section{Determination of Mineral Content}

Mineral content analysis of the dried powdered desert date kernel was carried out by transferring $5 \mathrm{~g}$ of the sample into a pre-weighed cleaned porcelain crucible and placing the crucible and its content into a muffle furnace at $550^{\circ} \mathrm{C}$ until a white grey ash was obtained. The residue ash was then dissolved in $5 \mathrm{ml}$ of $\mathrm{HNO}_{3} / \mathrm{HCl}(1: 2)$ and heated gently on a hot plate until the brown fumes disappeared and white coloration was formed. The solution on the crucible was then filtered into $100 \mathrm{ml}$ volumetric flask and the volume made up to $100 \mathrm{ml}$ with deionized water. The concentrations of potassium, calcium, sodium, magnesium, iron, manganese, zinc, copper, nickel, cobalt and chromium were determined using flame atomic absorption spectrophotometer (model VGP 210, Buck Scientific, USA) (Shahid et al., 1999; Datti et al., 2019).

\section{Extraction and Purification of the Oil}

The oil was extracted from the kernels of the desert date using the solvent extraction process, using petroleum ether as a solvent by soxhlet apparatus (Karamat et al., 2003; Adejumo et al., 2013; Ratna et al., 2014). For purification, the oil was taken in a separating funnel along with water $(100 \mathrm{ml})$, ether $(200 \mathrm{ml})$ and saturated sodium chloride the content was well shaken and then allowed to stand. The aqueous layer was then discarded and the process was repeated three times with organic layer. Finally the ethereal extract was taken in a conical flask and then dried over $20 \mathrm{~g}$ anhydrous sodium sulfate, and was evaporated at a temperature of $40^{\circ} \mathrm{C}$ to get the purified oil (Karamat et al., 2003; Ratna et al., 2014).

\section{Physical Characteristics of the Oil \\ Color of Oil}

The color of the extracted oil from the desert date kernel was observed visually as reported by Ogala et al., (2018).

Determination of Density and Specific Gravity of the Oil The density of the desert date oil was determined using prewashed, dried and labeled density bottles. The density bottled was then filled up to the volume mark with the oil sample, and the weight of the density bottle with the oil was determined. The density bottled was also filled up to the volume mark with the water, and the weight of the density bottle with the water was determined (Myles 2001; Brosk 2014). The density and the specific gravity of the oil were calculated using the formulae:

$$
\begin{gathered}
\text { Density }=\frac{W 2-W 1}{V} \\
\text { Specific Gravity }=\frac{W 2-W 1}{W 3-W 1}
\end{gathered}
$$

where:

W1 = Weight of Empty Density Bottle

W2 $=$ Weight of Density Bottle + Oil

W3 = Weight of Density Bottle + Water

$\mathrm{V}=$ Volume of Oil.

\section{Refractive Index of the Oil}

The refractive index of the oil was determined using Abbe- 60 refractometer (NYRL 3-Leica Mark, Leica Inc., Buffalo, New York) as described by AOAC (2008).

Viscosity of the Oil

The viscosity of the oil sample was investigation using the Ostwald-U-tube viscometer according to AOAC (2008). The viscometer was first suspended in a constant temperature water bath so that the capillary was vertical. The instrument was filled with the oil to the mark at the top of the lower reservoir with the aid of a pipette inserted in the side arm in such a way that the tube wall above the mark was not wetted. The instrument was then left to stand for 3 minutes before reading in order to equilibrate the sample temperature with that of the instrument $\left(35^{\circ} \mathrm{C}\right)$. By means of pressure on the respective arm of the tube, the oil moved into the other arm so that the meniscus was above the mark at the top of upper reservoir. Finally, the liquid was allowed to flow freely through the tube and the time required for the meniscus to pass from the mark above the upper reservoir to that at the bottom of the upper reserve was recorded.

Chemical Characteristics of B. aegyptiaca Kernel oil Acid Value of the Oil

Here $2 \mathrm{~g}$ of the test sample was transferred into a conical flask, and then $50 \mathrm{~cm}^{3}$ petroleum ether added and gently mixed. Ethanol $\left(50 \mathrm{~cm}^{3}\right)$ was then added into the mixture and titrated with $0.1 \mathrm{M} \mathrm{KOH}$ to pink colour (AOAC, 2008). The Acid value was calculated using the formula:

$$
\begin{aligned}
& \text { Acid Value }(\mathrm{mg} \mathrm{KOH} / \mathrm{g}) \\
& =\frac{\text { Titre Value } x \text { Normality } \times 56.1}{\text { Weight of Sample }} \\
& \% \text { Free Fatty Acid }=\frac{\text { Titre Value } \times 28.2 \times \text { Normality }}{\text { Weight of Sample }} \\
& 1 \mathrm{~cm}^{3} \text { of } 1 \mathrm{M} \mathrm{KOH}=56.1 \mathrm{mg} \text { of } \mathrm{KOH}
\end{aligned}
$$

FUDMA Journal of Sciences (FJS) Vol. 4 No. 2, June, 2020, pp 250 - 259 


\section{Peroxide Value of the Oil}

The peroxide value (PV) of desert date kernel oil was determined according to the procedure reported by Wail et al., (1995) and adopted by Mohamed and Mohammed (2018), where $1 \mathrm{~g}$ of the test sample was transferred into $250 \mathrm{ml}$ conical flask, then $30 \mathrm{ml}$ of a glacial acetic acid/chloroform solution (ratio 3:2) was added, and the flask was gently shaken until the sample was dissolved, and then $0.5 \mathrm{ml}$ of saturated potassium iodide was added. The solution was one again gently shaken for 1 minute, and $30 \mathrm{ml}$ of distilled water was added followed by $0.5 \mathrm{ml}$ of $1 \%$ starch solution. The content of the flask was later titrated with $0.1 \mathrm{~N}$ sodium thiosulphate with constant and vigorous shaking until the blue colour just disappeared. A blank test was also carried out in similar manner. The volume of the $0.1 \mathrm{~N}$ sodium thiosulphate required was recorded.

$$
P V=\frac{(V a-V b) N X 100}{W}
$$

where:

$\mathrm{Va}=$ Volume of sodium thiosulphate solution used in the titration

$\mathrm{Vb}=$ Volume of sodium thiosulphate solution used in the blank test

$\mathrm{W}=$ Weight of the sample in grams

$\mathrm{N}=$ Normality of sodium thiosulphate.

Saponification Value of the Oil

Determination of the saponification value of the desert date kernel oil was carried out according to the AOAC (2008) method, where $1 \mathrm{~g}$ of the oil sample was transferred into $200 \mathrm{ml}$ conical flask, and the $25 \mathrm{ml}$ of $0.1 \mathrm{~N}$ alcoholic $\mathrm{KOH}$ solution was added. The flask and its content were boiled under reflux for one hour with frequent rotation, then $1 \mathrm{ml}$ of phenolphthalein indicator was added while the solution was still hot, and the excess alkali was titrated with $0.5 \mathrm{~N} \mathrm{HCl}$, with the volume of $\mathrm{HCl}$ required to complete the titration recorded. The same procedure was repeated for the blank and the volume of $\mathrm{HCl}$ required to complete the titration also recorded.

$$
\text { Saponification Value }=\frac{(b-a) \times 0.02805 \times 1000}{S}
$$

where;

$\mathrm{a}=$ Volume of $\mathrm{HCl}$ used to titrate the sample

$\mathrm{b}=$ Volume of $\mathrm{HCl}$ used to titrate the blank

$\mathrm{S}=$ Weight of oil in gram.

Iodine Value of Oil

The iodine value (IV) of the oil sample was determined according to the BSI (1985) method as adopted by Mohamed and Mohammed (2018), where $0.26 \mathrm{~g}$ of the sample was weighed into a glass stoppered flask and then dissolved with 10 $\mathrm{ml}$ cyclohexane. Then $20 \mathrm{ml}$ of Wijs solution (iodine monochloride dissolved in acetic acid) was added and the flask was stoppered and then allowed to stand in the dark for 30 minutes at a temperature of $25^{\circ} \mathrm{C}$ after which $20 \mathrm{ml}$ of $10 \%$ potassium iodide solution was added. The mixture was then titrated against $0.1 \mathrm{M} \mathrm{Na}_{2} \mathrm{~S}_{2} \mathrm{O}_{3}$ using starch as the indicator. The analysis was then carried out using a blank, and the iodine value was calculated using the following formula (AOAC, 2008).

$$
\text { Iodine Value }=\frac{12.69 \times C(V 1-V 2)}{\text { Weight of Sample in gram }}
$$

where;

$\mathrm{C}=$ Concentration of $\mathrm{Na}_{2} \mathrm{~S}_{2} \mathrm{O}_{3}$ solution,

$\mathrm{V} 1=$ Volume of $\mathrm{Na}_{2} \mathrm{~S}_{2} \mathrm{O}_{3}$ used for the blank,

$\mathrm{V} 2=$ Volume of $\mathrm{Na}_{2} \mathrm{~S}_{2} \mathrm{O}_{3}$ used for the sample

Determination of Fat Content

The Gerber method for the determination of the fat content of the desert date kernel oil was employed in accordance with the procedure reported by Richardson, (1985) and adopted by Gemechu et al., (2015). Here $5 \mathrm{~mL}$ of each of the oil sample was mixed with $10 \mathrm{~mL}$ of sulphuric acid (specific gravity 1.82 ) into butyrometer and $1 \mathrm{~mL}$ of amyl alcohol was then added. The butyrometer was then closed with rubber cork, and the content was vigorously shaken until all the oil was digested by the acid. The butyrometer was then placed in a water bath at $65^{\circ} \mathrm{C}$ for 5 minutes. The sample was centrifuged for 5 minutes, and then transferred back to the water bath at $65^{\circ} \mathrm{C}$ for 5 minutes, and the percentage fat was recorded from the butyrometer.

\section{Free Fatty Acid (FFA) of the Oil Sample}

To determine the free fatty acid content of the desert date kernel oil, $2 \mathrm{~g}$ of the oil was placed in a $250 \mathrm{~mL}$ conical flask and warmed, and $2.5 \mathrm{~mL}$ of methanol was added with constant stirring, followed by 3 drops of phenolphthalein indicator, and this was then titrated against $0.14 \mathrm{M}$ potassium hydroxide solution with vigorous shaking until a permanent light pink color, which persisted for $1 \mathrm{~min}$, was observed (Afolabi, 2008; Ogala et al., 2018). The end point was recorded, and the free fatty acid value was calculated using equation.

where;

$$
\% \text { Free Fatty Acid }=\frac{V \times M \times 28.2}{W}
$$

$\mathrm{V}=$ Volume of potassium hydroxide used

$\mathrm{M}=$ Molarity of potassium hydroxide used

$\mathrm{W}=$ Weight of the Sample.

\section{RESULTS AND DISCUSSION \\ Results}

The results for the proximate composition and the mineral content of the desert date kernel are presented in Tables 1 and 2 respectively, while the physical and chemical characteristics of the desert date kernel oil are presented in Tables 3 and 4 respectively.

Table1: Proximate Composition of Desert Date Kernel

\begin{tabular}{lll}
\hline S/NO & Constituent & Mean concentration $(\%)$ \\
\hline 1 & Moisture Content & $3.19 \pm 0.0286$ \\
2 & Ash Content & $2.89 \pm 0.0498$ \\
3 & Fat Content & $39.63 \pm 0.5012$ \\
4 & Crude Protein Content & $33.75 \pm 0.1008$ \\
5 & Crude Fiber Content & $13.06 \pm 0.0473$ \\
6 & Carbohydrate Content & $7.48 \pm 0.0295$ \\
\hline
\end{tabular}

FUDMA Journal of Sciences (FJS) Vol. 4 No. 2, June, 2020, pp 250 - 259 
Table 2: Mineral Content of Desert Date Kernel

\begin{tabular}{lll}
\hline S/NO & Mineral & Mean Concentration $(\mathbf{m g} / \mathbf{1 0 0 g})$ \\
\hline 1 & Potassium & $1.120 \pm 0.019$ \\
2 & Calcium & $0.390 \pm 0.040$ \\
3 & Sodium & $0.801 \pm 0.016$ \\
4 & Magnesium & $0.142 \pm 0.098$ \\
5 & Iron & $0.0024 \pm 0.0016$ \\
6 & Manganese & $0.01512 \pm 0.0053$ \\
7 & Zinc & $0.0082 \pm 0.00043$ \\
8 & Copper & $0.00225 \pm 0.00021$ \\
9 & Nickel & $0.00582 \pm 0.00032$ \\
10 & Cobalt & $0.002623 \pm 0.00032$ \\
11 & Chromium & $0.003224 \pm 0.00051$ \\
\hline
\end{tabular}

Table 3: Physical Characteristics of the Oil

\begin{tabular}{llll}
\hline S/NO & Parameter & & FAO/WHO STANDARD \\
\hline 1 & Color & Pale Yellow & \\
2 & Density g/cm & \\
3 & Specific Gravity & 0.910 & 0.909 \\
4 & Refractive Index & $\mathbf{0 . 9 0 7}$ & $\mathbf{1 . 4 5 8}$ \\
5 & Viscosity & 19.68 & $1.4677-1.4705$ \\
\hline
\end{tabular}

Table 4: Chemical Characteristics of B. aegyptiaca Kernel Oil

\begin{tabular}{llll}
\hline S/NO & Parameter & Desert Date Kernel Oil & FAO/WHO Standard \\
\hline 1 & Acid Value $(\mathrm{mgKOH} / \mathrm{g})$ & 3.06 & 4 \\
2 & Free Fatty Acid & 1.27 & $5.78-7.28$ \\
3 & Peroxide Value $(\mathrm{mEq} / \mathrm{Kg})$ & 3.71 & $<10$ \\
4 & Saponification Value $(\mathrm{mg} / \mathrm{KOH} / \mathrm{g})$ & $198 \pm 0.16$ & $195-205$ \\
5 & Iodine Value 100/g & 98.73 & $80-106$ \\
\hline
\end{tabular}

\section{DISCUSSION}

Moisture content is one of the most important component of food processing, preservation and testing of foods. The amount of dry matter in a food is always inversely proportional to the amount of moisture it contains as such moisture content is of direct economic importance to both the consumer and processor. Of even greater significance, however, is the effect of moisture on the stability and quality of foods, with foods that contains too much water easily subjected to rapid deterioration from mold growth, bacterial attack, insect damage and sprouting (Pomeranz and Meloan 1994). The moisture content of the desert date kernel was found to be $3.19 \%$, and this was found to be below that reported by Jock (2011) and Ogala et al., (2018) who respectively reported moisture contents of $7.23 \%$ and $7.16 \%$. However, the findings of this study agree with reports by Sara and Mahdi (2016) who reported a moisture content of $3.74 \%$; Elbadawi et al., (2017) who reported $3.13 \%$, and Alhassan et al., (2018) who reported 4.08\%. The differences could be attributed to the variety of the plant available and the soil it was grown on (Gabriel et al., 2018).

Ash content refers to the inorganic residue remaining after either ignition or complete oxidation of organic matter in the food sample. The ash content is the measure of the total amount of minerals present within a food, with its determination along that of the mineral contents of the foods important in nutritional labeling of the food, microbiological stability and processing. It is also an important quality attribute for some food ingredients, as well as the first step in the preparation of a sample for specific elemental analysis (Baraem 2017). The ash content of the sample analyzed was found to be $2.89 \%$. This result was found to be in agreement with reports by Jock (2011); Sara and Mahdi (2016); Elbadawi et al., (2017); Alhassan et al., (2018) and Ogala et al., (2018).

Fats are one of the three main macronutrients, along with carbohydrates and proteins. Fat is an important foodstuff for many forms of life, and serves both structural and metabolic functions. They are a necessary part of the diet of both humans and animals, and the most efficient form of energy storage (Pickova 2009). The crude fat or oil content of the kernel of the desert date was found to be $39.63 \%$ and this result is supported by similar reports by Jock (2011); Lohlum (2012); Sara and Mahdi (2016); Elbadawi et al., (2017); Alhassan et al., (2018) and Ogala et al., (2018). The result is however lower than that reported by Elfeel (2010) who reported $50 \%$ fat content. Oil provides concentrated energy in the diet and enhanced palatability (Hassan et al., 2008). The high fat content of the kernel of the desert date is an indication that it can be a good source of fat.

Proteins are some highly complex substances present in all living organisms. They are said to be of great nutritional value, and directly involved in nearly all the chemical processes essential for life. They are also involved in growth and maintenance of the body; they cause biochemical reactions; they act as messengers; they provide structure to the body; they help in maintaining proper $\mathrm{pH}$; they maintain the balance of the body fluids; they bolsters the immune health; they transport and store nutrients; they also provide energy to the body (Shahidi and Senadheera 2019). In this study, the percentage protein

FUDMA Journal of Sciences (FJS) Vol. 4 No. 2, June, 2020, pp 250 - 259 
content of the kernel of the desert date was found to be $33.75 \%$ and this agrees with similar reports by Jock (2011); Lohlum (2012); Sara and Mahdi (2016); Elbadawi et al., (2017); Alhassan et al., (2018) and Ogala et al., (2018). Protein being an essential component of the diet required for the survival of both humans and animals (Pugalenthi et al., 2004), then kernel of the desert date can serve as a source of this important nutrient.

Crude fiber is usually a measure of the quantity of indigestible lignin, cellulose and other components. It consists largely of 60$80 \%$ cellulose and 4-6\% lignin, in addition to other mineral matter. There is an increasing need to include food rich in fibre diet, as they help to prevent colon cancer (Rock 2007; Haritha and Ayona 2017). Fibers also are essential in treating or preventing diverticulosis, hemorrhoids, coronary heart diseases and constipation (Chandaka et al., 2017). The kernel seed analyzed in this study was found to contain an appreciable amount of crude fibre $(13.06 \%)$, and this was found to agree with that reported by Jock (2011); Lohlum (2012); Sara and Mahdi (2016); Elbadawi et al., (2017); Alhassan et al., (2018) and Ogala et al., (2018). Crude fiber is known to expand the inside walls of the colon, easing the passage of waste, and this makes it quite effective against constipation (Betty et al., 2016).

Carbohydrates, alongside fats and proteins, are one of the three macronutrients in our diet with their main function being to provide energy to the body. Carbohydrates come in many different forms, ranging from sugars to dietary fibres, and in many different foods, such as whole grains, as well as fruit and vegetables (Cummings and Stephen 2007). The carbohydrate content of the desert date kernel analyzed in this study was found to be $7.48 \%$ and this agrees with that reported by Sara and Mahdi (2016); Elbadawi et al., (2017); Alhassan et al., (2018) and Ogala et al., (2018).The low carbohydrate content the kernel of the desert date means that the kernel is not an excellent source of carbohydrate.

The mineral content of the desert date kernel was found to be as follows; potassium $(1.120 \mathrm{mg} / 100 \mathrm{~g})$; calcium $(0.390$ $\mathrm{mg} / 100 \mathrm{~g}) ;$ sodium $(0.801 \mathrm{mg} / 100 \mathrm{~g})$; magnesium $(0.142$ $\mathrm{mg} / 100 \mathrm{~g})$; iron $(0.0024 \mathrm{mg} / 100 \mathrm{~g})$; manganese $(0.01512$ $\mathrm{mg} / 100 \mathrm{~g})$; zinc $(0.0082 \mathrm{mg} / 100 \mathrm{~g})$; copper $(0.00225 \mathrm{mg} / 100 \mathrm{~g})$; nickel $(0.00582 \mathrm{mg} / 100 \mathrm{~g})$; cobalt $(0.002623 \mathrm{mg} / 100 \mathrm{~g})$; chromium $(0.003224 \mathrm{mg} / 100 \mathrm{~g})$. The results show that the kernel is rich in potassium, calcium, sodium and magnesium, while other minerals are also present in appreciable amounts. The findings in this study agree with similar findings reported by Jock (2011); Lohlum (2012); Sara and Mahdi (2016); Elbadawi et al., (2017); Alhassan et al., (2018) and Ogala et al., (2018). Potassium and sodium are electrolytes needed for the body to function normally and help in maintaining the fluid and blood volume of the body. However, when there is an inbalance between the two, a person may develop high blood pressure, that is by consuming too much sodium and not enough potassium (USDHHS 2015). Potassium and sodium also help in regulating the water balance and the acid-base balance in the blood and tissues (Kowey 2002). Calcium is essential to maintaining total body health. Our bodies need calcium every day not just to keep our bones and teeth strong over but to ensure proper functioning of muscles and nerves, and also help our blood to clot. Calcium deficiency is usually due to an inadequate intake of the mineral when the blood calcium levels drop too low, as such how much calcium we get is very important to our health (Piste et al., 2013). Magnesium, the fourth most common mineral in the human body after calcium, sodium and potassium, is also the second most common intracellular cation after potassium. Magnesium is a cofactor in many enzyme systems and is also required for such fundamental processes as energy production and nucleic acid synthesis, and plays an important role in the synthesis of ATP (adenosine triphosphate) from ADP (adenosine diphosphate) and inorganic phosphate (Gerry and Stephen 2017). Copper helps the body form collagen and absorbs iron, and plays a role in energy production. Zinc plays a role in wound healing as well as treatment to diarrhea. Iron is a mineral that serves several important functions, its main function being to carry oxygen throughout our bodies and making red blood cells (Beard and Dawson 1997). Manganese, along with vitamin $\mathrm{K}$, plays a role in blood clotting and hemostasis (Aschner and Aschner 2005). It is also an essential trace element naturally present in many foods or available as a dietary supplement, and serves as a cofactor for many enzymes (Nielsen 2012; Buchman 2014). Due to the reasonable concentrations of some of these minerals in the desert date kernel, it can easily be said the kernel can serve as an excellent supplement for these minerals for human body.

The quality analysis of Balanites aegyptica kernel oil was done by analyzing some physical such as the oil color, its density, specific gravity, refractive index and viscosity. The observed colour of the oil was pale yellow, and this has been the findings of Ogala et al., (2018). The density of the kernel oil studied was found to be 0.910 which agrees with that reported by Babeker (2013) and just above that reported by Ogala et al., (2018) who reported 0.87 , and just below than that reported by Manji et al., (2013) who reported a value of 1.001. However, the finding of this study is within the FAO/WHO standards of 0.909 . The specific gravity of the desert date kernel oil in this study was found to be 0.907 , and this result is in agreement with that reported by Jock (2011) Manji et al., (2013) Haftu, (2015) Sara and Mahdi (2016) Elbadawi et al., (2017), and within the $0.9-1.16$ range set by the FAO/WHO standards. The refractive index of 1.458 is just a little below the FAO/WHO standard of 1.4677-1.4705, but still near similar to that reported by Babeker (2013) and Manji et al., (2013). The viscosity of 19.68 recorded in this however found to be in agreement with similar reports by Babeker (2013).

The acid value of $3.06 \mathrm{mgKOH} / \mathrm{g}$ and observed in this study is just below the FAO/WHO standard of $4 \mathrm{mgKOH} / \mathrm{g}$, but still shows that the oil is stable (Haftu, 2015). While the free fatty acid content of $1.27 \%$ is far below the FAO/WHO standard limits of $5.78-7.28 \%$. Oils with high acid value (above 4 $\mathrm{mgKOH} / \mathrm{g}$ ), also implying a high percentage free fatty acid content, will develop unpleasant smell and rancid odour due to the hydrolysis of the free fatty acids due to storage. The acid value and the percentage free fatty acid of Balanites aegyptica seed kernel oil are all lower than FAO/WHO standard for edible oils. The lower the percentage free fatty acid content the less the tendency of the oil to undergo hydrolytic activities. However, the results for the acid value and the free fatty acids obtained in this study are in agreement with similar findings by Manji et al., 2013 and Jock 2017, but lower than that reported by Ogala et al., 2018.

The peroxide value, used as a measure of the extent to which rancidity reactions have occurred during storage, is used as an indication of the quality and stability of fats and oils. The peroxide value determined for the kernel oil of Balanites

FUDMA Journal of Sciences (FJS) Vol. 4 No. 2, June, 2020, pp 250 - 259 
aegyptica was found to $3.71 \mathrm{mEq} / \mathrm{g}$ and is within the FAO/WHO standard of less than $10 \mathrm{mEq} / \mathrm{g}$, and the lower the peroxide value the more suitable is the oil for a long storage, implying longer shelf-life (Adegbe et al., 2016). The results of this study agree with similar reports by Mohammed et al., (2017) and Mohamed and Mohammed (2018), but far lower than reported by Babeker (2013) and Manji et al., (2013) who respectively reported 8.0 and $6.0 \mathrm{mEq} / \mathrm{g}$ ).

The saponification value, which is an index of average molecular mass of fatty acid in the oil sample, was found to be $198 \mathrm{mgKOH} / \mathrm{g}$ for Balanites aegyptica kernel oil analyzed, and this value is within the FAO/WHO range of 195-205 mg KOH/g for edible oils. The result agrees with similar reports by Babeker (2013), Manji et al., (2013), Mohammed et al., (2017) and Mohamed and Mohammed (2018). The saponification value of oil is an important quality in determining the suitability of the oil for soap making.

The iodine value measures the degree of unsaturation in fats or oils. It determines the stability of oils to oxidation and allows the overall unsaturation of the fat to be determined qualitatively. The iodine value of the desert date kernel oil analyzed in this study was found to be $98.73100 / \mathrm{g}$ and within the range of the FAO/WHO standard of $80-106100 / \mathrm{g}$. The result was in agreement to similar reports by Babeker (2013), Manji et al., (2013), Mohammed et al., (2017) and Mohamed and Mohammed (2018). Oils with iodine values below 100 are nondrying, while those having values between 100 -130 are semidrying and those with values above 130 are termed drying oils (Jock 2018).

\section{CONCLUSION}

Desert date has been in used traditionally for the treatment of many diseases and ailments. This study revealed that the seed kernel of this plant is of high nutritional value, and also contains many mineral elements in significant amounts. The oil of the seed of this plant can be a good source of raw material for many oil-based products like lubricants, shampoos, soap and biodiesel, more so, the oil could also be utilized as a an excellent source of edible oil for human consumption as it can make a good dietary source and/or supplement for some minerals.

\section{REFERENCES}

Abu-Al-Futuh IM. (1983): Balanites aegyptiaca: An Unutilized Raw Material Potential Ready for Agro-Industrial Exploitation. UNIDO Document No. 12419 Project TF/INT/77/021. UNIDO of the United Nations.

Adebayo SE., Orhevba BA., Adeoye PA., Fase OJ. and Musa JJ. (2012): Solvent Extraction and Characterizaion of oil from African Star Apple (Chrysophyllum albidum) Seeds. International Journal of Academic Research, 3:178-183.

Alhassan AJ., Muhammad IU., Idi A., Dangambo MA., Ramatu Y., Mohammad A., Nasir A.,. Yaradua AI., Adamu SM. and Alexander I. (2018): Phytochemical Screening and Proximate Analysis of Balanites aegyptiaca Kernel. Food Science and Quality Management 74:37-41.

Al-Thobaiti SA. and Abu-Zeid IM. (2018): Phytochemistry and Pharmaceutical Evaluation of Balanites aegyptiaca: An
Overview Journal of Experimental Biology and Agricultural Sciences, 6(3):453-465.

AOAC. (2008). Official Methods of Analysis, Association of Official Analytical Chemists, Washington D.C. (15th ed).

Aschner JL. and Aschner M. (2005): Nutritional Aspects of Manganese Homeostasis. Mol Aspects Med 26:353-362.

Author CC. (1995): Lipid-Based Fats Substitutes. Critical Review Science Nutrients Journal, 35:4-5.

Awe, IS. and Sodipo, OA. (2001): Purification of Saponins of Root of Blighia sapida Koenlg-Holl. Nigerian Journal of Biochem. Mol. Biol. 16(37):201-204.

Baraem PI. (2017): Ash Content Determination: Food Analysis Laboratory Manual Pp.117-119.

Bayero, AS., Datti Y., Shuaibu, MM., Nafisatu, AM., Asma'u, AA., Dikko, MA., Zakari, AH. and Yusuf, M. (2019): Phytochemical Screening and Antibacterial activity of the Root Bark Extracts of Neocarya macrophylla). ChemSearch Journal 10(2):41-45.

Beard JL. and Dawson HO. (1997) Iron, in O'Dell BL. Sunder RA Editors Handbook of Nutritionally Essential Mineral Elements, New York, CRC Press. Pp. 275-334.

Betty T., Jacob K.A., Faustina D.W., and Elsa I. O. (2016) Watermelon Seeds as Food: Nutrient Composition, Phytochemicals and Antioxidant Activity International Journal of Nutrition and Food Sciences 5(2):139-144.

Billore SKV. (1988): Balanites aegyptiaca: A Browse Plant of High Protein Value in Degraded Lands. In: Singh P, Pathak PS (Eds.), Rangelands Resources and Management, Pp. 350-355.

Brosk FAZ. (2014): Oil Properties Laboratory, 2nd stage, Petroleum Engineering Department, Petroleum Engineering Department, Koya University. Pp 4-6.

Buchman AR. (2014): Manganese. In: A. Catharine Ross BC, Robert J. Cousins, Katherine L. Tucker, Thomas R. Ziegler ed. Modern Nutrition in Health and Disease. 11th ed. Baltimore, MD: Lippincott Williams \& Wilkins; Pp. 238-244.

Chandaka M., Murali KK., Ramanji RK., Jhansi LP., Eswar KK (2017): Estimation of Crude Fibre Content from Natural Food Stuffs and its Laxative Activity Induced in Rats International Journal of Pharma Research and Health Sciences 5(3):17031706.

Chapagain BP., Lindin T., Wiesman Z. and Jaroszewski JW. (2006): Structural Analysis of Complex Saponins of Balanites aegyptiaca by $800 \mathrm{MHz} 1 \mathrm{H}$ NMR Spectroscopy. Magnetic Resonance in Chemistry 44:923-928.

Charity UZ., Alexander AJ., Hassan IG. and Yarkasuwa IC. (2018): Application of Desert Date (Balanites aegyptiaca) Seed Oil as Potential Raw Material in the Formulation of Soap and Lotion. American Journal of Analytical Chemistry, 9:423-437.

FUDMA Journal of Sciences (FJS) Vol. 4 No. 2, June, 2020, pp 250 - 259 
Chothani DL. and Vaghasiya HU. (2011): A Review on Balanites aegyptiaca Del (Desert Date): Phytochemical Constituents, Traditional Uses, and Pharmacological Activity. Pharmacognosy Reviews 5:55-62.

Chung KT., Wong TY., Wei CI., Huang YW. and Lin Y. (1998): Tannins and Human Health: A Review. Crit Rev Food Sci Nutr. 38(6):421-464.

Clement, AO., Jacob, GA., James, MK., Refaat, A. and Ahmed, A. (2011): Harvesting and Processing of Balanite aegyptiaca Leaves and Fruits for Local Consumption by Rural Communities in Uganda. Journal of Food Technology 9(2):8390 .

Cummings JH. and Stephen AM. (2007): Carbohydrate Terminology and Classification. European Journal of Clinical Nutrition 61:5-18.

Datti Y., Bayero AS., Salihu I., Isa BK., Musbahu L., Abubakar SA., Nafisa AM., Nura T. and Dikko MA. (2019): Chemical Composition and the Phytochemical Constituents of the Seeds of Sesame indicum Grown at Katsina State, Northern Nigeria. Food Science Journal 4(6):102-106.

Daya, LC. and Vaghasiya, HU. (2011): A Review on Balanite aegyptiaca Del (Desert Date) Phytochemical Constituents, Traditional Uses and Pharmacological Activity. Journal of Pharmacogn Rev, 5(9):55-62.

Egbuna C. and Ifemeje JC. (2015): Biological Functions and Anti-nutritional Effects of Phytochemicals in Living System. IOSR Journal of Pharmacy and Biological Sciences 10:10-19.

Elbadawi SMA., Ahmad EEM., Mariod AA. and Mathaus B. (2017). Effects of Thermal Processing on Physicochemical Properties and Oxidative Stability of Balanities aegyptiaca Kernels and Extracted Oil, Grasas Y Aceites 68(1):1-7.

Elfeel AA. (2010): Variability in Balanites aegyptiaca Var. aegyptiaca Seed Kernel Oil, Protein and Minerals Contents Between and Within Locations Agiculture and Biology Journal of North America, 1(2):170-174.

Elfeel AA. and Warrag EI. (2011): Uses and Conservation Status of Balanites aegyptiaca (L.) Del. (Hegleig Tree) in Sudan: Local People Perspective. Asian Journal of Agricultural Sciences 3:386-390.

Elseed AMAF., Amin AE., Khadiga A., Ali AA., Sekene J., Hishinum M. and Hamana K. (2002): Nutritive Evaluation of some Fodder Tree Species During the Dry Season in Central Sudan. Asian-Australasian Journal of Animal Sciences 15:844850

Francesca BG., Claire S., Everaldo A. and Lilian MA. (2015): Crude Fiber Determination of Malva sylvestris L. and Evaluation of its Faecal Bulking and Laxative Properties in Rats International Journal of Biology; 7(4):1-8.

Gabriel AF., Igwemmar N C., Sadam AA. and Babalola SA. (2018) Characterization of Seed Oil from Citrullus lanatus
(Watermelon) Direct Res. J. Public Health and Environ. Technol. 3(2):34-40.

Gemechu T., Beyene F. and Eshetu M. (2015): Physical and Chemical Quality of Raw Cow's Milk Produced and Marketed in Shashemene Town, Southern Ethiopia. Journal of Food and Agricultural Science 5(2):7-13.

Gerry KS. and Stephen JG. (2017): The Importance of Magnesium in Clinical Healthcare Scientifica 1-14.

Gloria, NE., Babajide, OE. and Ochuko, LE. (2011): Activities of some Enzymes, Enzyme Inhibitors and Antinutritional Factors from the Seeds of Sponge Gourd (Luffa aegyptiaca M.). African Journal of Biochemistry Research. 5(3):86-89.

Gnoula C., Megalizzi V. and De Neve N. (2008): Balanitin-6 and - 7: Diosgenyl Saponins Isolated from Balanites aegyptiaca Del. Display Significant Anti-Tumor Activity In-Vitro and InVivo. International Journal of Oncology, 32(1):5-15.

Guinand Y. and Lemessa D. (2001). Reflection on the Role of Wild Food and Famine Foods at a Time of Drough.Wild Foods Plants in Ethiopia. Workshop proceedings. USAID/OFDA. Mombassa, Kenya.

Gupta SC., Shenoy S. and Kotecha M. (2012): Pharmacognostical and Phytochemical Evaluation of Balanites aegyptica Del. Stem Bark. International Research Journal of Pharmacy 3:169-173.

Gutti B., Bamidele SS. and Bagaje IM. (2012): Characterization and Composition of Balanites aegyptiaca Seed Oil and its Potential as Biodiesel Feedstock in Nigeria. Journal of Applied Phytotechnology in Environmental Sanitation 1:29-35.

Hanan A., Al-Ashaal AF., Ayman MM., Abd EA. and Ali MA. (2009): Phytochemical Investigation and Medicinal Evaluation of Fixed Oil of Balanites aegyptiaca Fruits (Balantiaceae). Journal of Ethnopharmacology 2:495-501.

Harborne JB. (1998): Phytochemical Methods. A Guide to Modern Technique of Plant Analysis. Chapman \& Hall London. Pp. 260-269.

Haritha MC. and Ayona J. (2017): Comparative Study of Moisture, Crude Fibre, Protein and Mineral Composition in Five Varieties of Cassava (Manihot esculenta Crantz) Tubers International Journal for Research in Applied Science \& Engineering Technology (IJRASET) 5(9):1954-1959.

Hassan LG., Dangoggo SM., Umar KJ., Saidu I. and Folorunsho FA. (2008). Proximate, Minerals and AntiNutritional Factors of Daniellia oliveri seed kernel. Chemclass Journal, 5:31-36.

Ifeoma II., Chukwunonso EE., Obinna MN. and Bryan CN. (2010): Effect of Traditional Processing Techniques on the Nutritional and Phytochemical Composition of African BreadFruit (Treculia africana) Seeds Journal of Applied Science and Environmental Management. 14(4):169 - 173. 
Jock AA. (2011) Physicochemical and Phytochemical Characterization of Seed Kernel Oil from Desert Date (Balanites Aegyptica) Journal of Chemical Engineering and Bio-Analytical Chemistry 2(1):49-61.

Kamel M. (1991): Study of Balanites aegyptiaca Del. and Salvadora persica L. Reputed to Have Hypoglycemic Effects, Department of Pharmacognosy, Faculty of Pharmacy, Assiut, Egypt.

Kowey PR. (2002): The Role of Potassium. In: Lobo R.A., Crosignani P.G., Paoletti R., Bruschi F. (eds) Women's Health and Menopause. Medical Science Symposia Series, Springer, Boston, MA. Vol 17. Pp. 151-157.

Kumawat BK., Gupta M., Chand T. and Singh Y. (2012): Prelimenary Phytochemical Investigation on Leaves of Balanites aegyptiaca (L.). Research Journal of Pharmaceutical, Biological and Chemical Sciences. 3(2):762-768.

Locket CT., Calvert CC. and Grivetti LE. (2000): Energy and Micronutrient Composition of Dietary and Medicinal Wild Plants Consumed During Drought. Study of Rural Fulani, Northeastern Nigeria. International Journal of Food Science 51(3):195-208.

Lohlum SA., Forcados EG., Agida OG., Ozele N. and Gotep JG. (2012): Enhancing the Chemical Composition of Balanites aegyptiaca Seeds through Ethanol Extraction for Use as a Protein Source in Feed Formulation, Sustainable Agriculture Research; 1(2):251-255.

Myles JM. (2001): Methods for the Determination of Specific Gravity, Chandler Engineering Company N. Indianwood Avenue Broken Arrow, Oklahoma 74012. Pp 22-24.

Monica B. and Ioan S. (2018): Essential Oils from Plants Journal of Biotechnology and Biomedical Science 1(4):35-43.

Nasser SA., Alaa SA., Salwa IAW., Ibtisam MHE., Mohamed YH. and Hussein MA. (2016): Antidiabetic and Antioxidant Impacts of Desert Date (Balanites aegyptiaca) and Parsley (Petroselinum sativum) Aqueous Extracts: Lessons from Experimental Rats, Journal of Diabetes Research 2016:01-10.

Nielsen FH. (2012): Manganese, Molybdenum, Boron, Chromium, and Other Trace Elements. In: John W. Erdman Jr. IAM, Steven H. Zeisel, ed. Present Knowledge in Nutrition. 10th ed: Wiley-Blackwell; Pp. 586-607.

Obidah W., Nadro MS., Tiyafo GO. and Wurochekke AU. (2009) Toxicity of Crude Balanites aegyptiaca Seed Oil in Rats. The Journal of American Science 5:13-16.

Ogala H., Elinge CM., Wawata IG., Adegoke A., Muhammad AB. and Ige AR. (2018): Extraction and Physicochemical Analysis of Desert Date (Balanite aegyptiaca) Seed Oil. International Journal of Advanced Academic Research 4(4):112.
Olaofe O. and Sanni CO. (1988): Nutritional Component of some Non-Conventional Leaf Vegetable Consumed in Cameroon. Food Chemistry 30:73-77.

Patel SS. and Savjani JK. (2015): Systematic Review of Plant Steroids as Potential Antiinflammatory Agents: Current Status and Future Perspectives The Journal of Phytopharmacology 4(2):121-125.

Pearson D. (1981): The Chemical Analysis of Food (8 ${ }^{\text {th }}$ Ed). J. A. Churchill London. Pp. 535.

Pickova J. (2009): Importance of Knowledge on Lipid Composition of Foods to Support Development towards Consumption of Higher Levels of n-3 Fatty Acids via Freshwater Fish. Physiol. Res. 58(1):39-45.

Piste P., Didwagh S. and Mokashi A. (2013) Calcium and its Role in Human Body International Journal of Research in Pharmaceutical and Biomedical Sciences 4(2):659-668.

Pomeranz Y. and Meloan CE. (1994): Determination of Moisture. In: Food Analysis. Springer, Boston, MA Pp 575601.

Pugalenthi M., Vadivel V., Gurumoorthi P., and Janardhanan D. (2004). Comparative Nutritional Evaluation of Little Known Legumes, Tamarindus indica, Erythrina indica, and Sesbania bispinosa. Trop. Subtrop. Agroecosyst. 4:107-123.

Rock CL. (2007): Primary Dietary Prevention: Is the Fiber Story Over?: Recent Results Cancer Res 174:171-177.

Shahidi F. and Senadheera R. (2019): Protein-Phenol Interactions: Encyclopedia of Food Chemistry 2:532-538.

Sara MEF and Mahdi ASS. (2016): Physicochemical Properties of Balanites aegyptiaca (Laloub) Seed Oil. Journal of Biological Science, 2(4):1-10.

Selouka MA., Fouteye MML., Hasni OT., Abdelkarim FM. and Ali OMSB. (2020): Phytochemicals, Antioxidant Activity and Ethnobotanical Uses of Balanites aegyptiaca (L.) Del. Fruits from the Arid Zone of Mauritania, Northwest Africa Plants 9(401):1-15.

Tripathi IP. and Mishra C. (2015): Phytochemical Screening of some Medicinal Plants of Chitrakoot Region, Indian Journal of Applied Research 5(12):56-60.

U.S. Department of Health and Human Services, USDHHS, (2015): U.S. Department of Agriculture. Scientific Report of the 2015 Dietary Guidelines Advisory Committee CDC. Washington, DC: U.S. Department of Health and Human Services.

Vaidehi P. and Rajesh P. (2016): The Active Constituents of Herbs and their Plant Chemistry, Extraction and Identification Methods: Journal of Chemical and Pharmaceutical Research, 8(4):1423-1443.

FUDMA Journal of Sciences (FJS) Vol. 4 No. 2, June, 2020, pp 250 - 259 
Vonmaydell HJ. (1986): Trees and Shrubs of the Sahel: Their Characteristics and Uses. Eschborn, GTZ, Germany, Pp. 525.

Yadav JP. and Panghal M. (2010): Balanites aegyptiaca (L.) Del. (Hingot): A Review of its Traditional Uses, Phytochemistry and Pharmacological Properties. International Journal of Green Pharmacy 4:140-146.
Yubin JI., Miao Y., Bing W. and Yao Z. (2014): The Extraction, Separation and Purification of Alkaloids in the Natural Medicine Journal of Chemical and Pharmaceutical Research, 6(1):338-345. 